
3 Research Square

\title{
Impact of COVID-19 pandemic on mortality count at the Emergency Ward of Hospitals in India: A Cross- sectional study from January 2019 to May 2021
}

Dr Piyush Kumar ( $\sim$ drpiyush003@gmail.com )

Health Department, Government of Bihar https://orcid.org/0000-0001-9857-478X

\section{Research Article}

Keywords: Emergency department, Death, COVID-19, Pandemic, Health facilities

Posted Date: March 2nd, 2022

DOl: https://doi.org/10.21203/rs.3.rs-1245972/v2

License: (c) (1) This work is licensed under a Creative Commons Attribution 4.0 International License.

Read Full License 


\section{Abstract}

Background-Acute treatment in emergency case management is required for survival and stabilization of critical patients, followed by shifting the patients to the relevant department for further care. However, for the seriously ill critical patients struggling for survival, the care is provided by the Emergency Department/Ward (ED) of the hospital as the situation is not enough to enable transfer because death may occur while transferring and treatment in such situations are given at emergency ward/department. This aspect of emergency management care is often overlooked by policy makers and government which is really serious regarding who dies in the ED. Aim and Objective-The aim of this cross sectional research study was to determine impact of COVID-19 pandemic era on mortality count at the emergency ward of public-private-rural-urban hospitals in India across 36 states and union territories. The objective was fulfilled by collecting, observing, analyzing total mortality occurring at the emergency ward of publicprivate-rural-urban hospitals in India from 1st January 2019 to 31st May 2021(linear regression is not done for forecasting due to two factors, first the COVID-19 situation and mortality is changing as well as largely associated with virulence of strain and to keep data from accredited source intact on real grounds) of emergency department admissions of public and private health facilities. The objective was to find out if there is increase or decrease in mortality of emergency department admissions during the COVID-19 pandemic era by comparing mean mortality of ED per month of public, private, rural, urban health facilities before the pandemic from 1st and 2nd year of pandemic i.e. 2020 and 2021 respectively.

Methods-This research study is a cross sectional retrospective mixed qualitative and quantitative analysis of the mortality occurring at the emergency department of public and private, rural, urban hospitals from 1st January 2019 to May31st 2021 with aim to find out impact of COVID-19 pandemic era on mortality at ED. Electronic patient records from HMIS (health management information system) of MoHFW (ministry of health and family welfare) , Government of India is collected, observed, analyzed, compared for all patients deaths occurring at Emergency Department (ED) of public and private, rural, urban health facilities $(n=452102)$ during the study period from 1st January 2019 to 31st May 2021.

Results-The study results found that largest total number of death occurred in the ED during may 2021 whereas the least number of deaths occurred in February 2019 (limitation is actual data availability is up to May 2021 from accredited sources and linear regression is avoided to keep study based on real data only, hence forecast for adjustment was avoided). During the first year of the pandemic, mean mortality per month (Jan2020-Dec2020) in the emergency department (ED) of rural, urban, public and private hospitals in India was 16067per month whereas before the pandemic it was 12542 per month while during second year of pandemic i.e. 2021 the mean mortality increased to 21758 per month (up to May 2021).

Conclusion-Due to novel nature of COVID-19 disease, the majority of hospital clinicians have challenging situation during this COVID-19 pandemic era as well as emergency ward (EW) medical-nonmedical teams faced a sudden sharp increase in the number of cases with limited available resources. Furthermore, a lack of proper knowledge of COVID-19 added with confusion and lack of timely revised directives for 
treatment may have hindered proper care/treatment, as witnessed in many part of the world and available in various literatures. This situation may have increased mortality during COVID-19 pandemic era at emergency wards of various health facilities. The authors hope that this study will help global researchers as well as policy makers to promote further research and discussion into preparation methods/strategies for such pandemics to reduce patient mortality in the ED.

\section{Introduction}

\section{Background/rationale}

Acute treatment in emergency case management is required for survival and stabilization of critical patients, followed by a shifting to the relevant medical department for further care. However, for the seriously ill critical patients, i.e., when the care provided by the Emergency Department (ED) of the hospital is not enough to enable transfer, death may occur while treatment in the emergency department. This aspect of emergency management is often overlooked, and very few researcher and government is really serious regarding who dies in the ED. This research is a cross-sectional retrospective study of the mortality occurring at the emergency ward / department of public-private-urban-rural hospitals from $1^{\text {st }}$ January 2019 to May31 2021 with aim to find out impact of COVID-19 pandemic era on mortality at ED. The first global case of COVID-19 was reported from Wuhan city in Hubei province of China during December 2019 and since then a state of acute emergency is prevailing on around the globe [1].

For better understanding the impact of the SARS-CoV-2 pandemic on hospital healthcare, I have studied mortality occurring in the emergency department/ward (ED) of rural, urban, public and private hospitals in India across 36 states and union territories during this COVID-19 pandemic era and compared it with the period before January 2020 when this pandemic has not accounted for a single documented case in India. The World Health Organization (WHO) declared on March 11, 2020, the novel coronavirus (SARSCoV-2) outbreak a global pandemic [2]. The first documented case in India was found in January 2020 hence up to December 2019 mortality in ED was considered as pre-pandemic era deaths in this research study [3]. India had reported the first documented death from COVID-19 on 12 March 2020 from the state of Karnataka [4].

Starting from Dec 2019 SARS-CoV-2 caused a global pandemic of disease resulting in substantial excess mortality and major disruption to healthcare. The first year i.e. 2020 COVID-19 cases in India and other counties globally prompted government to enforce a national lockdown which had also reduced OPD (out patient department) patients of different non-communicable diseases and worldwide health services disruptions were seen [5]. Lockdown measures changed during the second year 2021 of pandemic and COVID-19 vaccination programme started countrywide in 2021[6]. During this pandemic, healthcare restructuring and modification is going on from local to national levels in anticipation of predicted needs. Reports of reductions in OPD for non-COVID-19 acute illnesses have raised questions that several patients may not have attended hospital for an acute illness. There are several factors influencing hospital admission during the pandemic such as fear of acquiring SARS-CoV-2 infection [7]. In India, 
acute hospital treatment/care is given to patients reporting directly to the emergency ward/department (ED) of any hospital or if required referred by their primary health centre to higher canters [8].

\section{Objectives}

The aim of this cross-sectional research study was to determine the total Mortality occurring in India from $1^{\text {st }}$ January 2019 to $31^{\text {st }}$ May 2021 (linear regression is not done for forecasting adjustments due to two factors, first the COVID-19 situation and mortality is changing as well as largely associated with virulence of strain [9] and to keep data from accredited source intact on real grounds) of emergency department admissions of all public-rural-urban and private health facilities across 36 states and union territories of India which are registered on HMIS. The objective is to find out if there is increase or decrease in mortality at ED during the COVID-19 pandemic era by comparing mean mortality per month before the pandemic from $1^{\text {st }}$ and $2^{\text {nd }}$ year of pandemic i.e. 2020 and 2021 respectively (also called first and second wave which author feels a misnomer as the wave definition and terminology in context of COVID-19 is not established and there are also small waves in between as well as different countries have different peaktime of cases and mortality due to COVID-19 pandemic).

\section{Methods}

\section{Study design}

This research study is a cross sectional retrospective analysis of the mortality occurring at the emergency ward / department of hospitals in India from $1^{\text {st }}$ January 2019 to May3 $1^{\text {st }} 2021$ with aim to find out impact of COVID-19 on average mortality.

\section{Setting, locations, and relevant dates}

Website Electronic patient records of HMIS (health management information system) of MoHFW (ministry of health and family welfare) , Government of India is collected, observed, analyzed, compared for all patients deaths occurring at Emergency Department (ED) of all health facilities $(n=452102)$ in India during the period $1^{\text {st }}$ January 2019 to $31^{\text {st }}$ May 2021.

\section{Exposure, follow-up, and data collection}

I have extracted data from the health management information system (HMIS) for all ED patients mortality occurring at the Emergency Department of rural, urban, public and private health facilities in India from $1^{\text {st }}$ January 2019 to $31^{\text {st }}$ May 2021 of all ages and gender $(n=452102)$. In next version of this research study data for IPD (inpatient department) medical admissions from the HMIS for pre and pandemic era will also be included for better epidemiological analysis and understanding. The data were recorded, calculated and analyzed with Microsoft office and Stata software. 
The participants were anyone who died at ED of any health facility of India during study period and registered at HMIS of MoHFW.

\section{Variables}

Months, Number of deaths occurring at Emergency Department, Total deaths occurring at Emergency Department deaths occurring at Emergency Department of-Public [A]-Private [B]-Urban [C]-Rural [D] health facilities of India are key variables.

\section{Data sources/measurement}

Data source-HMIS-MoHFW- https://hmis.nhp.gov.in/\#!/standardReports

\section{Bias}

The researcher feels study should include more periods of observations to reduce the bias. The next version will include more period as well as linear regression will be done for necessary adjustments.

\section{Study size}

The study size includes all patients deaths occurring at Emergency Department/ward (ED) of all health facilities ( $n=452102)$ and registered on HMIS in India for the period 1st January 2019 to 31st May 2021. This research study was done exclusively to know COVID-19 impact on mortality during pandemic era at emergency wards, hence the researcher have done this exclusive study. The researcher would like to clear that these mortalities were due to any disease/accidents/COVID-19 etc. and not exclusively due to SARSCoV-2 infections.

\section{Quantitative variables}

1. Number of deaths occurring at Emergency Department 2.Total deaths occurring at Emergency Department deaths occurring at Emergency Department of-Public [A]-Private [B]-Urban [C]-Rural [D] health facilities of India

\section{Results}

\section{Participants}

Anyone admitted to emergency ward and died at any health facility ED in India across 36 states and union territories whose information data is registered with HMIS, MoHFW, and Government of India.

\section{Descriptive data}

This research study included all residents of India, of all ages, of any sex, religion, caste etc. The cause of death is not specific but place of death is specific i.e. ED of any health facility in India. Anyone died of 
any cause and not only COVID-19 was included in the study. Of course the deaths due to SARS-CoV-2 infection are also included.

\section{Outcome data}

The outcome data were presented as table 1,2, and 3, 4, 5, 6 and figures 1, 2, 3, 4 and 5 .

Table-1- Month wise comparison of Mortality at all public-private-urban-rural health facilities of India in 2019 (pre-pandemic era) 


\begin{tabular}{|c|c|c|c|c|c|c|c|c|}
\hline Month-Year & Item & Number of deaths & Total & All India & & & & \\
\hline Month-Year & $\begin{array}{l}\text { Item } \\
\text { code } \\
\text { HMIS }\end{array}$ & $\begin{array}{l}\text { Number of deaths } \\
\text { occurring at Emergency } \\
\text { Department }\end{array}$ & Total & $\begin{array}{l}\text { Total } \\
{[(A+B) \text { or }} \\
(C+D)]\end{array}$ & $\begin{array}{l}\text { Public } \\
{[\mathrm{A}]}\end{array}$ & $\begin{array}{l}\text { Private } \\
\text { [B] }\end{array}$ & $\begin{array}{l}\text { Urban } \\
{[C]}\end{array}$ & $\begin{array}{l}\text { Rural } \\
{[D]}\end{array}$ \\
\hline Jan-19 & 14.7 & $\begin{array}{l}\text { Number of deaths } \\
\text { occurring at Emergency } \\
\text { Department }\end{array}$ & TOTAL & 15011 & 14709 & 302 & 1619 & 13392 \\
\hline Feb-19 & 14.7 & $\begin{array}{l}\text { Number of deaths } \\
\text { occurring at Emergency } \\
\text { Department }\end{array}$ & TOTAL & 9740 & 9442 & 298 & 1513 & 8227 \\
\hline Mar-19 & 14.7 & $\begin{array}{l}\text { Number of deaths } \\
\text { occurring at Emergency } \\
\text { Department }\end{array}$ & TOTAL & 14280 & 13824 & 456 & 1663 & 12617 \\
\hline Apr-19 & 14.7 & $\begin{array}{l}\text { Number of deaths } \\
\text { occurring at Emergency } \\
\text { Department }\end{array}$ & TOTAL & 11833 & 11511 & 322 & 1516 & 10317 \\
\hline May-19 & '14.7' & $\begin{array}{l}\text { Number of deaths } \\
\text { occurring at Emergency } \\
\text { Department }\end{array}$ & TOTAL & 12077 & 11691 & 386 & 1710 & 10367 \\
\hline Jun-19 & '14.7' & $\begin{array}{l}\text { Number of deaths } \\
\text { occurring at Emergency } \\
\text { Department }\end{array}$ & TOTAL & 12308 & 11834 & 474 & 1763 & 10545 \\
\hline Jul-19 & '14.7' & $\begin{array}{l}\text { Number of deaths } \\
\text { occurring at Emergency } \\
\text { Department }\end{array}$ & TOTAL & 12501 & 12063 & 438 & 1700 & 10801 \\
\hline Aug-19 & '14.7' & $\begin{array}{l}\text { Number of deaths } \\
\text { occurring at Emergency } \\
\text { Department }\end{array}$ & TOTAL & 13085 & 12619 & 466 & 2012 & 11073 \\
\hline Sep-19 & '14.7' & $\begin{array}{l}\text { Number of deaths } \\
\text { occurring at Emergency } \\
\text { Department }\end{array}$ & TOTAL & 11914 & 11488 & 426 & 1649 & 10265 \\
\hline Oct-19 & '14.7' & $\begin{array}{l}\text { Number of deaths } \\
\text { occurring at Emergency } \\
\text { Department }\end{array}$ & TOTAL & 13972 & 13421 & 551 & 2400 & 11572 \\
\hline Nov-19 & '14.7' & $\begin{array}{l}\text { Number of deaths } \\
\text { occurring at Emergency } \\
\text { Department }\end{array}$ & TOTAL & 12069 & 11614 & 455 & 1637 & 10432 \\
\hline Dec-19 & '14.7' & $\begin{array}{l}\text { Number of deaths } \\
\text { occurring at Emergency } \\
\text { Department }\end{array}$ & TOTAL & 11716 & 11320 & 396 & 1631 & 10085 \\
\hline Total & '14.7' & $\begin{array}{l}\text { Number of deaths } \\
\text { occurring at Emergency } \\
\text { Department }\end{array}$ & Total & 150506 & 145536 & 4970 & 20813 & 129693 \\
\hline Mean/month & '14.7' & $\begin{array}{l}\text { Number of deaths } \\
\text { occurring at Emergency } \\
\text { Department }\end{array}$ & Total & 12542.1 & 12128 & 414.166 & 1734.4 & 10807.7 \\
\hline
\end{tabular}

Table-2 - Month wise comparison of Mortality at all public-private-urban-rural health facilities of India in 2020 (first year of pandemic era) 


\begin{tabular}{|c|c|c|c|c|c|c|c|c|}
\hline Month-Year & $\begin{array}{l}\text { Item } \\
\text { code } \\
\text { HMIS }\end{array}$ & $\begin{array}{l}\text { Number of deaths } \\
\text { occurring at Emergency } \\
\text { Department }\end{array}$ & TOTAL & All India & & & & \\
\hline Month-Year & $\begin{array}{l}\text { Item } \\
\text { code } \\
\text { HMIS }\end{array}$ & $\begin{array}{l}\text { Number of deaths } \\
\text { occurring at Emergency } \\
\text { Department }\end{array}$ & TOTAL & $\begin{array}{l}\text { Total } \\
{[(A+B) \text { or }} \\
(C+D)]\end{array}$ & $\begin{array}{l}\text { Public } \\
{[\mathrm{A}]}\end{array}$ & $\begin{array}{l}\text { Private } \\
\text { [B] }\end{array}$ & $\begin{array}{l}\text { Urban } \\
{[C]}\end{array}$ & $\begin{array}{l}\text { Rural } \\
{[D]}\end{array}$ \\
\hline Jan-20 & '14.7' & $\begin{array}{l}\text { Number of deaths } \\
\text { occurring at Emergency } \\
\text { Department }\end{array}$ & TOTAL & 14136 & 13696 & 440 & 2330 & 11806 \\
\hline Feb-20 & '14.7' & $\begin{array}{l}\text { Number of deaths } \\
\text { occurring at Emergency } \\
\text { Department }\end{array}$ & TOTAL & 12689 & 12225 & 464 & 2616 & 10073 \\
\hline Mar-20 & '14.7' & $\begin{array}{l}\text { Number of deaths } \\
\text { occurring at Emergency } \\
\text { Department }\end{array}$ & TOTAL & 10887 & 10471 & 416 & 1463 & 9424 \\
\hline Apr-20 & '14.7 & $\begin{array}{l}\text { Number of deaths } \\
\text { occurring at Emergency } \\
\text { Department }\end{array}$ & TOTAL & 14185 & 13831 & 354 & 4821 & 9364 \\
\hline May-20 & '14.7 & $\begin{array}{l}\text { Number of deaths } \\
\text { occurring at Emergency } \\
\text { Department }\end{array}$ & TOTAL & 14201 & 13707 & 494 & 6026 & 8175 \\
\hline Jun-20 & '14.7 & $\begin{array}{l}\text { Number of deaths } \\
\text { occurring at Emergency } \\
\text { Department }\end{array}$ & TOTAL & 14782 & 13967 & 815 & 5853 & 8929 \\
\hline Jul-20 & '14.7 & $\begin{array}{l}\text { Number of deaths } \\
\text { occurring at Emergency } \\
\text { Department }\end{array}$ & TOTAL & 12354 & 11423 & 931 & 5976 & 6378 \\
\hline Aug-20 & '14.7 & $\begin{array}{l}\text { Number of deaths } \\
\text { occurring at Emergency } \\
\text { Department }\end{array}$ & TOTAL & 17005 & 16494 & 511 & 7165 & 9840 \\
\hline Sep-20 & '14.7 & $\begin{array}{l}\text { Number of deaths } \\
\text { occurring at Emergency } \\
\text { Department }\end{array}$ & TOTAL & 18056 & 17546 & 510 & 10142 & 7914 \\
\hline Oct-20 & '14.7 & $\begin{array}{l}\text { Number of deaths } \\
\text { occurring at Emergency } \\
\text { Department }\end{array}$ & TOTAL & 25014 & 22275 & 2739 & 13444 & 11570 \\
\hline Nov-20 & '14.7 & $\begin{array}{l}\text { Number of deaths } \\
\text { occurring at Emergency } \\
\text { Department }\end{array}$ & TOTAL & 22384 & 19679 & 2705 & 8567 & 13817 \\
\hline Dec-20 & '14.7 & $\begin{array}{l}\text { Number of deaths } \\
\text { occurring at Emergency } \\
\text { Department }\end{array}$ & TOTAL & 17111 & 16486 & 625 & 7303 & 9808 \\
\hline Total & $' 14.7^{\prime}$ & $\begin{array}{l}\text { Number of deaths } \\
\text { occurring at Emergency } \\
\text { Department }\end{array}$ & TOTAL & 192804 & 181800 & 11004 & 75706 & 117098 \\
\hline Mean/month & '14.7' & $\begin{array}{l}\text { Number of deaths } \\
\text { occurring at Emergency } \\
\text { Department }\end{array}$ & TOTAL & 16067 & 15150 & 917 & 6308.83 & 9758.16 \\
\hline
\end{tabular}


Statistical analysis: The data for mortality occurring at the Emergency Department of health facilities in India from 1st January 2019 to 31 st May 2021 is analyzed with stata and presented below in table 4, 5 and 6. The lockdown and unlock down periods are mentioned to show a little scenario of impacts of both, hence included the timeline. ED mortality increased sharply from August 2020 following the Unlock 2.0: 1 July 2020 - 31 July 2020 (31 days). From March 2021 the ED mortality have seen a tremendous rise following Unlock 10.0: 1 March 2021 - 31 March 2021 (31 days) see figure-1. The Government of India had declared a nationwide lockdown on $24^{\text {th }}$ march 2020 as listed below and this lockdown has also disrupted many other essential services [3]

Table-3- Month wise comparison of Mortality at public-private-urban-rural health facilities of India in 2021 (second year of pandemic era)

\begin{tabular}{|c|c|c|c|c|c|c|c|c|}
\hline Month-Year & & Number of deaths occurring & TOTAL & All India & & & & \\
\hline Month-Year & $\begin{array}{l}\text { Item } \\
\text { code } \\
\text { HMIS }\end{array}$ & $\begin{array}{l}\text { Number of deaths occurring } \\
\text { at Emergency Department }\end{array}$ & TOTAL & $\begin{array}{l}\text { Total } \\
{[(A+B) \text { or }} \\
C+D)]\end{array}$ & $\begin{array}{l}\text { Public } \\
{[\mathrm{A}]}\end{array}$ & $\begin{array}{l}\text { Private } \\
{[B]}\end{array}$ & $\begin{array}{l}\text { Urban } \\
{[C]}\end{array}$ & $\begin{array}{l}\text { Rural } \\
{[D]}\end{array}$ \\
\hline Jan-21 & '14.7 & $\begin{array}{l}\text { Number of deaths occurring } \\
\text { at Emergency Department }\end{array}$ & TOTAL & 18089 & 15013 & 3076 & 8302 & 9787 \\
\hline Feb-21 & '14.7 & $\begin{array}{l}\text { Number of deaths occurring } \\
\text { at Emergency Department }\end{array}$ & TOTAL & 18261 & 16905 & 1356 & 10683 & 7578 \\
\hline Mar-21 & '14.7 & $\begin{array}{l}\text { Number of deaths occurring } \\
\text { at Emergency Department }\end{array}$ & TOTAL & 14219 & 13277 & 942 & 6838 & 7381 \\
\hline Apr-21 & '14.7 & $\begin{array}{l}\text { Number of deaths occurring } \\
\text { at Emergency Department }\end{array}$ & TOTAL & 21846 & 18957 & 2889 & 10480 & 11366 \\
\hline May-21 & '14.7 & $\begin{array}{l}\text { Number of deaths occurring } \\
\text { at Emergency Department }\end{array}$ & TOTAL & 36377 & 32613 & 3764 & 21881 & 14496 \\
\hline Total & '14.7 & $\begin{array}{l}\text { Number of deaths occurring } \\
\text { at Emergency Department }\end{array}$ & TOTAL & 108792 & 96765 & 12027 & 58184 & 50608 \\
\hline Mean/month & '14.7' & $\begin{array}{l}\text { Number of deaths occurring } \\
\text { at Emergency Department }\end{array}$ & TOTAL & 21758.4 & 19353 & 2405.4 & 11636.8 & 10121.6 \\
\hline
\end{tabular}

Table-4- Statistical analysis of Pre-pandemic era 


\begin{tabular}{|l|l|l|l|l|l|l|}
\hline Pre-pandemic era summary statistics & No. of Obs & \multicolumn{4}{|l|}{ Deaths occurring at Emergency Department } \\
\hline Variable & Obs & Mean & Std. Dev. & Min & Max \\
\hline Total & 12 & 12542.17 & 1394.251 & 9740 & 15011 \\
\hline Public health facility & 12 & 12128 & 1370.285 & 9442 & 14709 \\
\hline Private health facility & 12 & 414.1667 & 76.75798 & 298 & 551 \\
\hline Urban health facility & 12 & 1734.417 & 245.9277 & 1513 & 2400 \\
\hline Rural health facility & 12 & 10807.75 & 1304.842 & 8227 & 13392 \\
\hline Confidence Interval- means & \multicolumn{2}{|c|}{ Deaths occurring at Emergency Department } \\
\hline Variable & No. of Obs & Mean & Std. Err. & [95\% Conf. & Interval] \\
\hline Total & 12 & 12542.17 & 402.4856 & 11656.3 & 13428.03 \\
\hline Public health facility & 12 & 12128 & 395.5671 & 11257.36 & 12998.64 \\
\hline Private health facility & 12 & 414.1667 & 22.15812 & 365.397 & 462.9364 \\
\hline Urban health facility & 12 & 1734.417 & 70.99322 & 1578.162 & 1890.672 \\
\hline Rural health facility & 12 & 10807.75 & 376.6756 & 9978.693 & 11636.81 \\
\hline
\end{tabular}

\{(Lockdown Phase 1: 25 March 2020 - 14 April 2020 (21 days)-Lockdown Phase 2: 15 April 2020 - 3 May 2020 (19 days)-Lockdown Phase 3: 4 May 2020 - 17 May 2020 (14 days)-Lockdown Phase 4: 18 May 2020 - 31 May 2020 (14 days)\}. The lockdown strategy is found effective to control the COVID-19 outbreak but there are several limitations to impose lockdown for longtime [10]. Hence the government of India started unlock as follow [11]:\{Unlock down 1.0: 1 June 2020 - 30 June 2020 (30 days)-Unlock down 2.0: 1 July 2020 - 31 July 2020 (31 days)-Unlock down 3.0: 1 August 2020 - 31 August 2020 (31 days)Unlock down 4.0: 1 September 2020 - 30 September 2020 (30 days)-Unlock down 5.0: 1 October 2020 - 31 October 2020 (31 days)-Unlock down 6.0: 1 November 2020 - 30 November 2020 (30 days)-Unlock 7.0: 1 December 2020 - 31 December 2020 (31 days)-Unlock down 8.0: 1 January 2021 - 31 January 2021 (31 days)-Unlock down 9.0: 1 February 2021 - 28 February 2021 (28 days)-Unlock down 10.0: 1 March 2021 31 March 2021 (31 days)-Unlock down 11.0: 1 April 2021 - 30 April 2021 (30 days)-Unlock down 12.0: 1 May 2021 - 31 May 2021 (31 days)-Unlock down 13.0: 1 June 2021 - 30 June 2021 (30 days)-Unlock down 14.0: 1 July 2021 - 31 July 2021 (31 days)-Unlock down 15.0: 1 August 2021 -

31 August 2021 (31 days)-Unlock down 16.0 : 1 September 2021 - 30 September 2021 (30 days)-Unlock down 17.0 : 1 October 2021 - 31 October 2021 (31 days)-Unlock down 18.0: 1 November 2021-

30 November 2021 (30 days)-Unlock down 19.0: 1 December 2021-31 December 2021 (31 days)-Unlock down 20.0: 1 January 2022-31 January 2022 (9 days) 


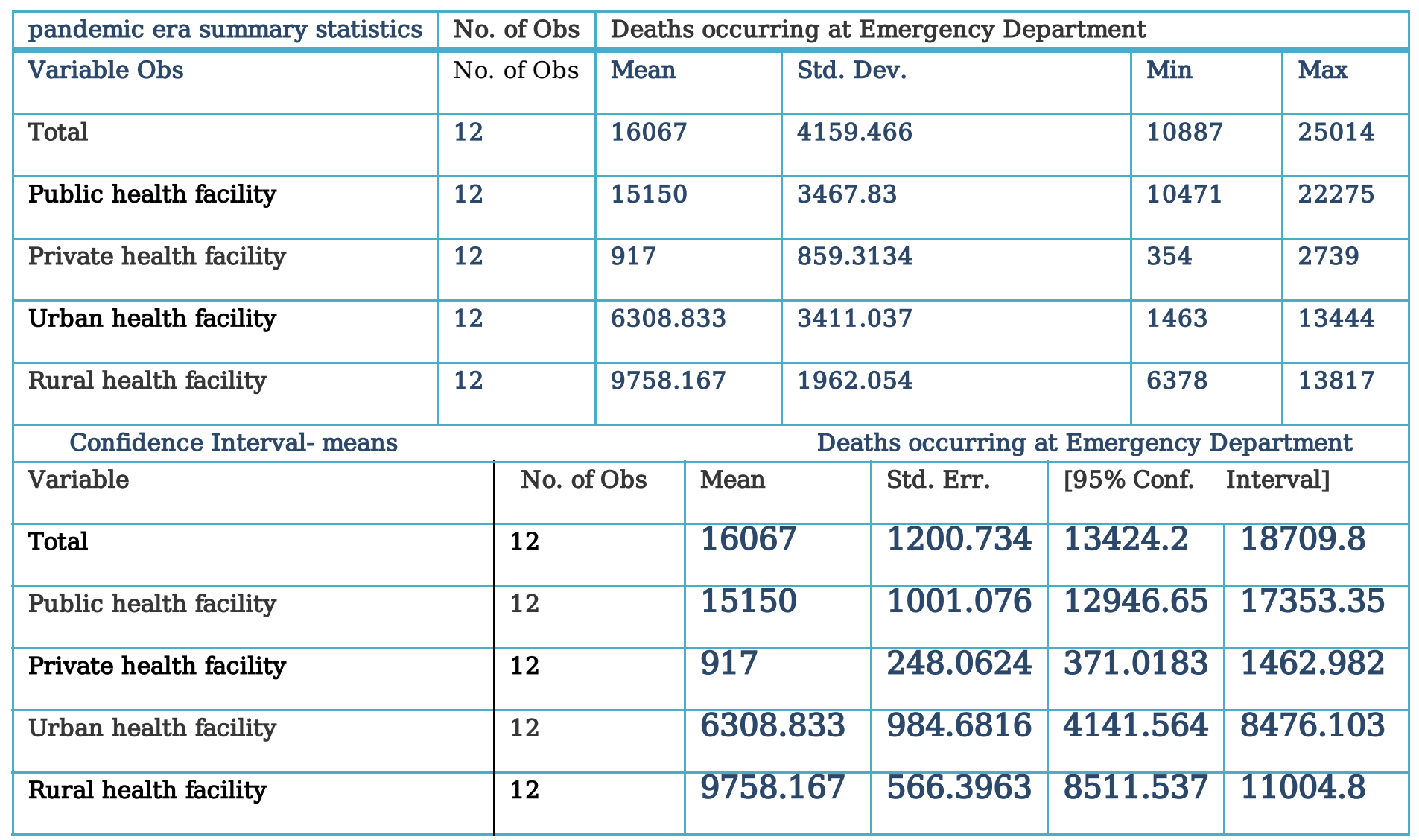

Table-6- Statistical analysis of second-pandemic era-2021

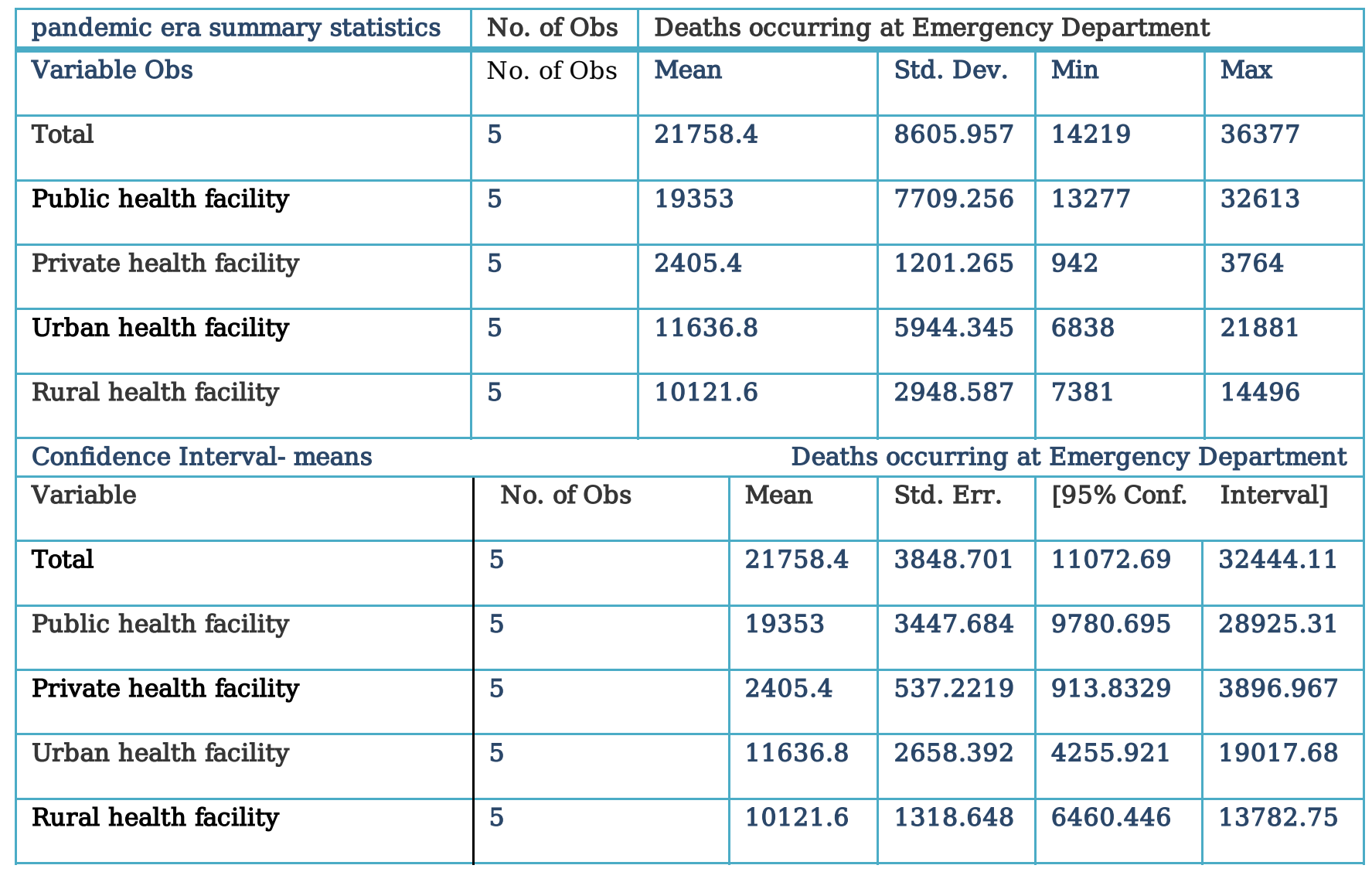




\section{Main results}

\section{A. Impact of COVID-19 pandemic on number of death occurring at the Emergency Department of all health facilities cumulative}

The study results found that largest total number of death occurred in the ED during may 2021 whereas the least number of deaths occurred in February 2019 (linear regression is not done for forecasting adjustments due to two factors, first the COVID-19 situation and mortality is changing as well as largely associated with virulence of strain [9] and to keep data from accredited source intact on real grounds). During the first year of the pandemic, average cumulative mortality per month (Jan2020-Dec2020) in the emergency department (ED) of rural, urban, public and private hospitals in India was 16067per month whereas before the pandemic it was 12542 per month while during second year of pandemic i.e. 2021 the average mortality increased to 21758 per month (up to May 2021) see table1, 2, and 3, 4, 5, 6 and figures $1,2,3,4$ and 5 .

Compared to the pre-pandemic era, in the $1^{\text {st }}$ year of pandemic era the total number of deaths occurring at Emergency Department of rural, urban, public and private hospitals increased 1.28 times or 3525 per month average increase is seen see figure 1, Table 1 and 2 . Compared to pre-pandemic era in the second year of pandemic era the number of deaths occurring at Emergency Department increased 1.73 times or 9216 per month average increase is seen see figure 1, Table 1 and 3.

B. Impact of COVID-19 pandemic on number of death occurring at the Emergency Department of public health facilities

The study results found that largest total number of death occurred in the ED of public health facility during may 2021 whereas the least number of deaths occurred in February 2019 (limitation is data availability up to May 2021 from accredited sources). During the first year of the pandemic, average mortality per month (Jan2020-Dec2020) in the emergency department (ED) of public hospitals in India was 15150 per month whereas before the pandemic it was 12128 per month while during second year of pandemic i.e. 2021 the average mortality increased to 19353 per month (up to May 2021).

Compared to pre-pandemic era in the first year of pandemic era the total number of deaths occurring at Emergency Department of public health facility increased 1.24 times or 3022 per month average increase is seen see figure 2, Table 1 and 2. Compared to pre-pandemic era in the second year of pandemic era the number of deaths occurring at Emergency Department of public health facility increased 1.59 times or 7225 per month average increase is seen see figure-2, Table 1 and 3.

C. Impact of COVID-19 pandemic on number of death occurring at the Emergency Department of private health facilities The study results found that largest total number of death occurred in the ED of private health facility during may 2021 whereas the least number of deaths occurred in February 2019 (limitation 
is data availability from accredited sources). During the first year of the pandemic, average mortality per month (Jan2020-Dec2020) in the emergency department (ED) of private hospitals in India was 917 per month whereas before the pandemic it was 414 per month while during second year of pandemic i.e. 2021 the average mortality increased to 2405 per month (up to May 2021).

Compared to pre-pandemic era in the first year of pandemic era the total number of deaths occurring at Emergency Department of private health facility increased 2.21 times or 503 per month average increase is seen see figure 3, Table 1 and 2. Compared to pre-pandemic era in the second year of pandemic era the number of deaths occurring at Emergency Department of private health facility increased 5.80 times or 1991 per month average increase is seen see figure 3,Table 1 and 3.

D. Impact of COVID-19 pandemic on number of death occurring at the Emergency Department of urban health facilities

The study results found that largest total number of death occurred in the ED of urban health facility during may 2021 whereas the least number of deaths occurred in March 2020 (limitation is data availability up to may 2021 from accredited sources). During the first year of the pandemic, average mortality per month (Jan2020-Dec2020) in the emergency department (ED) of urban hospitals in India was 6308 per month whereas before the pandemic it was 1734 per month while during second year of pandemic i.e. 2021 the average mortality increased to 11636.8 per month (up to May 2021).Compared to pre-pandemic era in the first year of pandemic era the average total number of deaths occurring at Emergency Department of urban health facility increased 3.64 times or 4574 per month average increase is seen see figure 4, Table 1 and 2. Compared to pre-pandemic era in the second year of pandemic era the number of deaths occurring at Emergency Department of urban health facility increased 6.71 times or 9902 per month average increase is seen see figure 4,Table 1 and 3.

E. Impact of COVID-19 pandemic on number of death occurring at the Emergency Department of rural health facilities The study results found that largest total number of death occurred in the ED of rural health facility during may 2021 whereas the least number of deaths occurred in July 2020 (limitation is data availability up to may 2021 from accredited sources).

During the first year of the pandemic, average mortality per month (Jan2020-Dec2020) in the emergency department (ED) of rural hospitals in India was 9758 per month whereas before the pandemic it was 10807 per month while during second year of pandemic i.e. 2021 the average mortality reduced to 10121 per month (up to May 2021).Compared to pre-pandemic era in the first year of pandemic era the average total number of deaths occurring at Emergency Department of rural health facility reduced by 1.12 times or 1049 per month average decrease is seen see figure 5, Table 1 and 2. Compared to pre-pandemic era in the second year of pandemic era the number of deaths occurring at Emergency Department of rural health facility reduced by 1.07 times or 686 per month average decrease is seen see figure 5,Table 1 and 3. 
Here it is remarkable to note that compared to pre-pandemic era in the first year of pandemic era the average total number of deaths occurring at Emergency Department of rural health facility reduced by 1.12 times or 1049 per month average decrease is seen as well as compared to pre-pandemic era in the second year of pandemic era the number of deaths occurring at Emergency Department of rural health facility reduced by 1.07 times or 686 per month average decrease is seen, whereas the urban facilities of healthcare has reported an increase in mortality during COVID-19 pandemic years. This may be due to shifting or referral of critical patients to urban higher centers. Still in India it's very unfortunate that urban population is still devoid of higher tertiary centers.

The study results found that largest total number of death occurred in the ED of public health facility during may 2021 whereas the least number of deaths occurred in February 2019 (limitation is data availability from accredited sources). During the first year of the pandemic, average mortality per month (Jan2020-Dec2020) in the emergency department (ED) of public hospitals in India was 15150 per month whereas before the pandemic it was 12128 per month while during second year of pandemic i.e. 2021 the average mortality increased to 19353 per month (up to May 2021).

Compared to pre-pandemic era in the first year of pandemic era the total number of deaths occurring at Emergency Department of public health facility increased 1.24 times or 3022 per month average increase is seen see Table 1 and 2. Compared to pre-pandemic era in the second year of pandemic era the number of deaths occurring at Emergency Department of public health facility increased 1.59 times or 7225 per month average increase is seen see Table 1 and 3 .

\section{Discussion}

The emergence of new virulence strains had disrupted healthcare as well as the normal life and lockdown and other measures are being implemented by different countries to save lives. The mortality at ED are having various etiologies, clinical severity at time of admission has a direct correlation with mortality, which requires the necessity of advanced triage system. There exists a lack of proper knowledge and advanced directives in the beginning i.e. December 2019 of the COVID-19 pandemic era. Of all the facilities only rural facilities reported reduced mortality during COVID-19 pandemic era. This may be due to shifting or referral of critical patients to urban higher centers. India healthcare system is struggling like global healthcare systems and it's very unfortunate that rural population is still devoid of higher tertiary centers [17].

\section{Study strengths and limitations}

This is the first article of its kind in the literature, to my knowledge, that has studied, investigated the impact of COVID-19 on the number of death occurring at the Emergency Department of rural, urban, public, private health facilities from COVID-19/SARS-CoV-2 pandemic in 36 states and union territories of India. One of the most peculiar strength is that the research study data were gathered from reliable accredited sources of Government Health Department and only real data reported is taken for study without forecast. I have analyzed the impact of COVID-19 on the number of death occurring at the 
Emergency Department starting from beginning of pandemic. This is exceptional and totally new idea to determine the ED mortality trends during a pandemic. A limitation is that author has not calculated some epidemiological indicators taking into account the health facility population coverage of the different zones. Another limitation is availability of more data from accredited sources. This limitation will be tried to remove in next version with more data and more epidemiological correlations. The comparison between different health facilities will be added in next version.

\section{Conclusions}

Due to novel disease majority of clinicians have challenging situation as well as Emergency Medicine (EM) medical-paramedical teams faced a sudden increase in the number of cases with limited resources which may be responsible for increased mortality during the pandemic-era. Furthermore, a lack of proper knowledge and directives may have hindered access to proper care, as witnessed in many part of the world and available in various literatures. The authors hope that this study will help global researchers as well as policy makers to promote further research and discussion into preparation methods for such pandemics to reduce patient's risk of death in the ED. Less ED mortality in the first year of the pandemic have given opportunities for reducing ED mortality in the future, but due to delayed or missed care, lack of skill, knowledge, capacity building of medical-paramedical teams and certainly management failure we have seen rise in mortality during second year of pandemic up to the study period observation. Of course there is limitation to this finding. This research study have identified major changes in ED mortality during the pandemic era and highlight the profound impact of a pandemic on emergency care, even for non-pandemic illness. The author is hopeful that this research study will form a foundation for policy makers for planning to minimize the impact in the future. This research is very broad and to reduce the length of article a short description of facts is presented in this version. More information and advanced analysis will be presented in next version by the author.

\section{Declarations}

\section{Funding}

The author declares that this research is self funded by researcher and no fund has been taken for this research study from any individual or agencies.

Note: - This article is available only as pre-print and not published by any peer-reviewed journals. The author has written previously on this research. There are chances of full/partial text and data overlapping with my own preprints previous works as well as this work is fully/partially available as preprints mentioned below in the references $[12,13,14,15$ and 16$]$.

\section{Availability of data and materials}

Web based Electronic patient records of HMIS (health management information system) of MoHFW (ministry of health and family welfare), Government of India 
-This version of paper has not been previously published in any peer reviewed journal and is not currently under consideration by any journal. The document is Microsoft word with English (United States) language and 6217 words Total including all.

- Ethics approval and consent to participate: Not applicable. This study has not involved any human or animals in real or for experiments. The submitted work does not contain any identifiable patient/participant information.

-Consent for publication: The author provides consent for publication.

-Availability of data and materials: Electronic records from HMIS (health management information system) of MoHFW (ministry of health and family welfare), Government of India.

-Conflicts of Interest/ Competing Interest: There are no conflicts / competing of interest

- Funding-Self sponsored. No aid taken from individual or agency etc.

- Authors' contributions: The whole work is done by the Author - Dr Piyush Kumar, M.B.B.S., E.M.O.C., P.G.D.P.H.M., -Senior General Medical Officer- Bihar Health Services- Health Department- Government of Bihar, India.

- Acknowledgements- I am thankful to advocate Anupama my wife and daughters Aathmika-Atheeva for cooperation. This article is available only as pre-print and not published by any peer-reviewed journals. The author has written previously on this research. There are chances of full/partial text and data overlapping with my own preprints previous works as well as this work is fully/partially available as preprints mentioned above in the references $[12,13,14,15$ and 16$]$.

- Author information: The author is currently working as Senior General Medical Officer for the government of Bihar.

-Financial Support \& sponsorship: Nil

-Author contact information

Department of Health, Government of Bihar, MOBILE - +919955301119/+917677833752, Email drpiyush003@gmail.com

\section{Abbreviations}

Emergency Department (ED); COVID-19-coronavirus disease-2019, SARS CoV-2-severe acute respiratory syndrome-coronavirus-2; HMIS (health management information system); MoHFW (ministry of health and family welfare); WHO (World Health Organization); Emergency Medicine (EM) 


\section{References}

1. Piyush Kumar (2022) What Impacts Have Geographical Locations On The Cases And Deaths From Covid-19/SarsCov-2 Pandemic In 36 States And Union Territories Of India:-Observational Analysis In India. J Mari Scie Res Ocean, 5(1): 01-07. Available at - https://opastonline.com/open-access/whatimpacts-have-geographical-locations-on-the-cases-and-deaths-from-covid-19sars-cov-2-pandemic-in-36states-and-union-territories-of-india-observational-analysis-in-india.pdf ; DOI - https://doi.org/10.33140/jmsro.05.01.01

2. WHO (World Health Organization), Director-General's opening remarks at the media briefing on COVID19 - 11 March 2020 - available at - https://www.who.int/director-general/speeches/detail/who-directorgeneral-s-opening-remarks-at-the-media-briefing-on-covid-19-11-march-2020

3. Dr. Piyush Kumar. (2022). What is the impact of Covid-19 on the Antenatal Care Services Utilization in Public-Private-Rural-Urban Hospitals of India during the COVID-19 Pandemic Period of 2020-2021 compared to pre-pandemic era 2018-2019?. MODERN APPLIED MEDICAL RESEARCH ISSN: 2582-9181, 2(2), 1-10. https://doi.org/10.36099/mamr.220522

4. The Hindu- India's first COVID-19 death confirmed in Karnataka- https://www.thehindu.com/scitech/health/indias-first-COVID-19-death-confirmed-in-karnataka-total-number-of-cases-cross70/article31053153.ece

5. WHO (World Health Organization),-COVID-19 significantly impacts health services for Noncommunicable diseases - available at - https://www.who.int/news/item/01-06-2020-covid-19significantly-impacts-health-services-for-noncommunicable-diseases

6. MoHFW (ministry of health and family welfare) - Revised Guidelines for implementation of National COVID Vaccination Program- available at - https://www.mohfw.gov.in/pdf/RevisedVaccinationGuidelines.pdf

7. Factors associated with hospital admission and critical illness among 5279 people with coronavirus disease 2019 in New York City: prospective cohort study BMJ 2020; 369 doi: https://doi.org/10.1136/bmj.m1966 (Published 22 May 2020) Cite this as: BMJ 2020; 369:m1966

8. Directorate General of Health Services Ministry of Health \& Family Welfare Government of India- Indian Public Health Standards (IPHS) Guidelines for Primary Health Centers Revised 2012 - available at - http://clinicalestablishments.gov.in/WriteReadData/360.pdf

9. WHO (World Health Organization)-Tracking SARS-CoV-2 variants- available at - https://www.who.int/en/activities/tracking-SARS-CoV-2-variants/

10. WHO (World Health Organization)-COVID-19 STRATEGY UPDATE- available at - https://www.who.int/docs/default-source/coronaviruse/covid-strategy-update-14april2020.pdf 
11. Ministry of Home Affairs, Government of India, visit- https://www.mohfw.gov.in/pdf/Annexure_MHA.pdf

12 Kumar, Piyush and Kumar, Piyush, What Impact Have COVID-19 Pandemic on Number of Death Occurring at the Emergency Department: A Retrospective Analysis of Mortality in India from January 2019 to May 2021 (January 10, 2022). Available at

SSRN: https://ssrn.com/abstract=4005178 or http://dx.doi.org/10.2139/ssrn.4005178

13. Kumar, Piyush and Kumar, Piyush, What impact Have COVID-19 Pandemic on Number of Death Occurring at the Emergency Department: A Retrospective Analysis of Mortality in India from January 2019 to May 2021. Available at

SSRN: https://ssrn.com/abstract=4006146 or http://dx.doi.org/10.2139/ssrn.4006146

14. Kumar, D. (2022, January 10). What impacts have Covid-19 pandemic on number of death occurring at the Emergency Department: A Retrospective Analysis of Mortality in India from January 2019 to May 2021. https://doi.org/10.31219/osf.io/cekaj

15. Dr Piyush Kumar. What impact have Covid-19 pandemic on number of death occurring at the Emergency Department: A Retrospective Analysis of Mortality in India from January 2019 to May 2021, 12 January 2022, PREPRINT (Version 1) available at Research Square https://doi.org/10.21203/rs.3.rs1245972/v1

16. DR PIYUSH KUMAR. (2022). what impacts have Covid-19 pandemic on number of death occurring at the Emergency Department: A Retrospective Analysis of Mortality in India from January 2019 to May 2021. Qeios, Doi: https://doi.org/10.32388/1HH8A5 .

17. Singh, S., \& Badaya, S. (2014). Health care in rural India: A lack between need and feed. South Asian journal of cancer, 3(2), 143-144. https://doi.org/10.4103/2278-330X.130483

\section{Figures}

Figure 1

Monthly cumulative death comparison graph at ED of all health facilities 


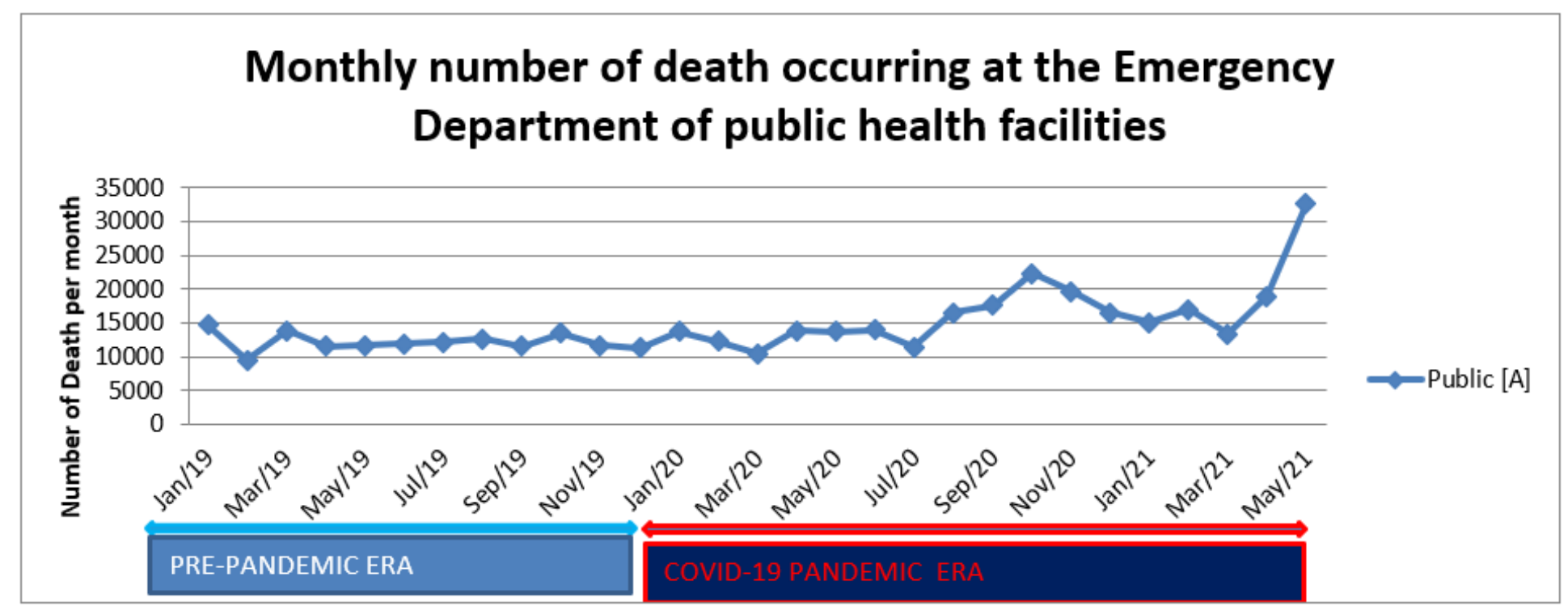

Figure 2

Monthly death comparison graph at ED of public health facilities in India

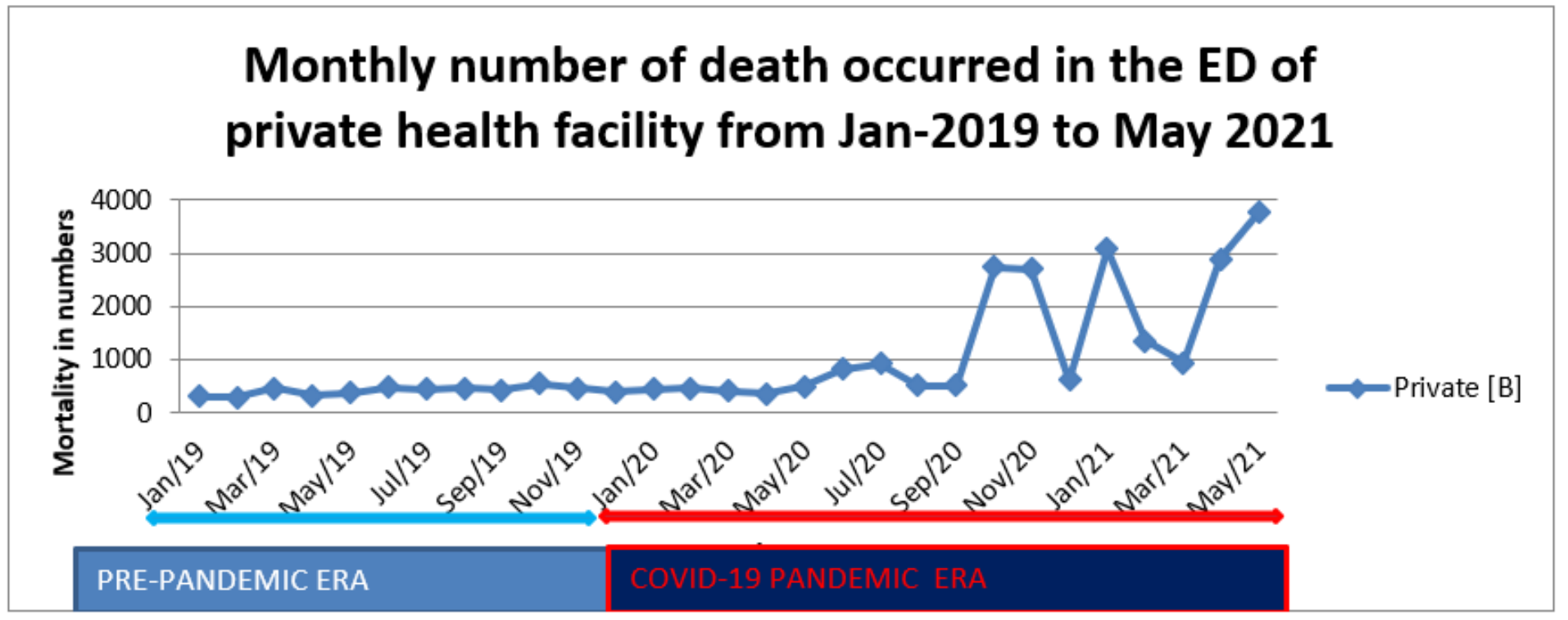

Figure 3

Month wise death comparison graph at ED of private health facilities in India 


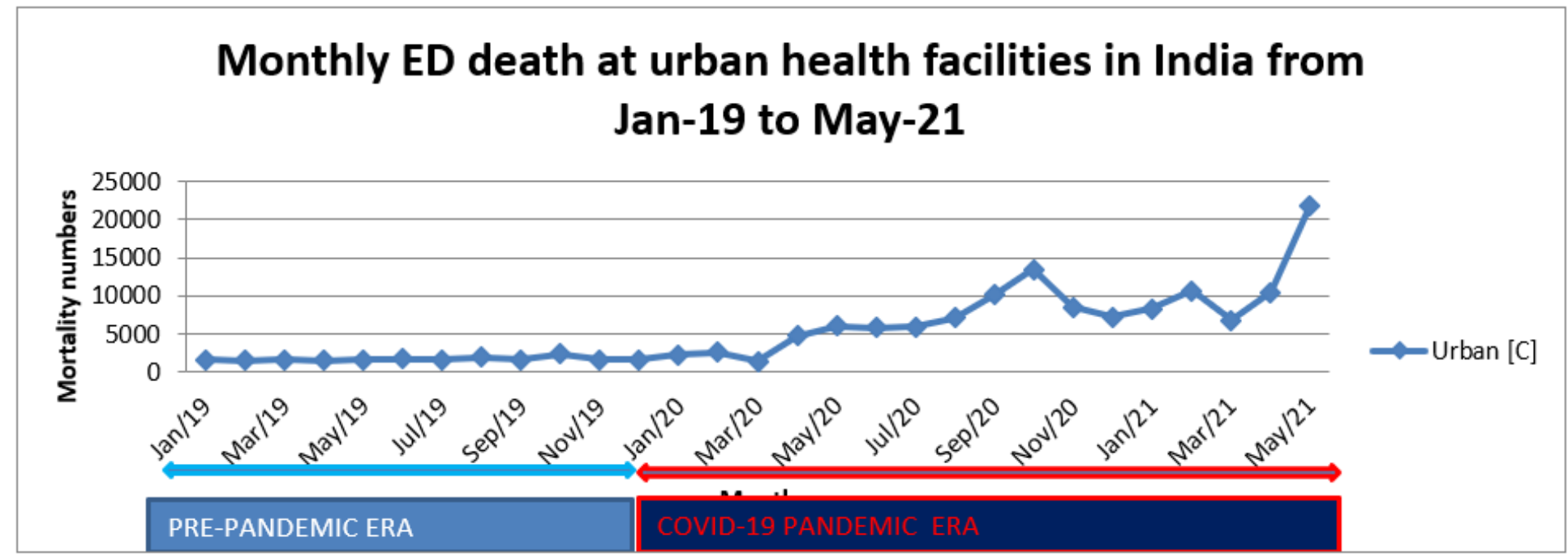

Figure 4

Month wise death comparison graph at ED of urban health facilities in India

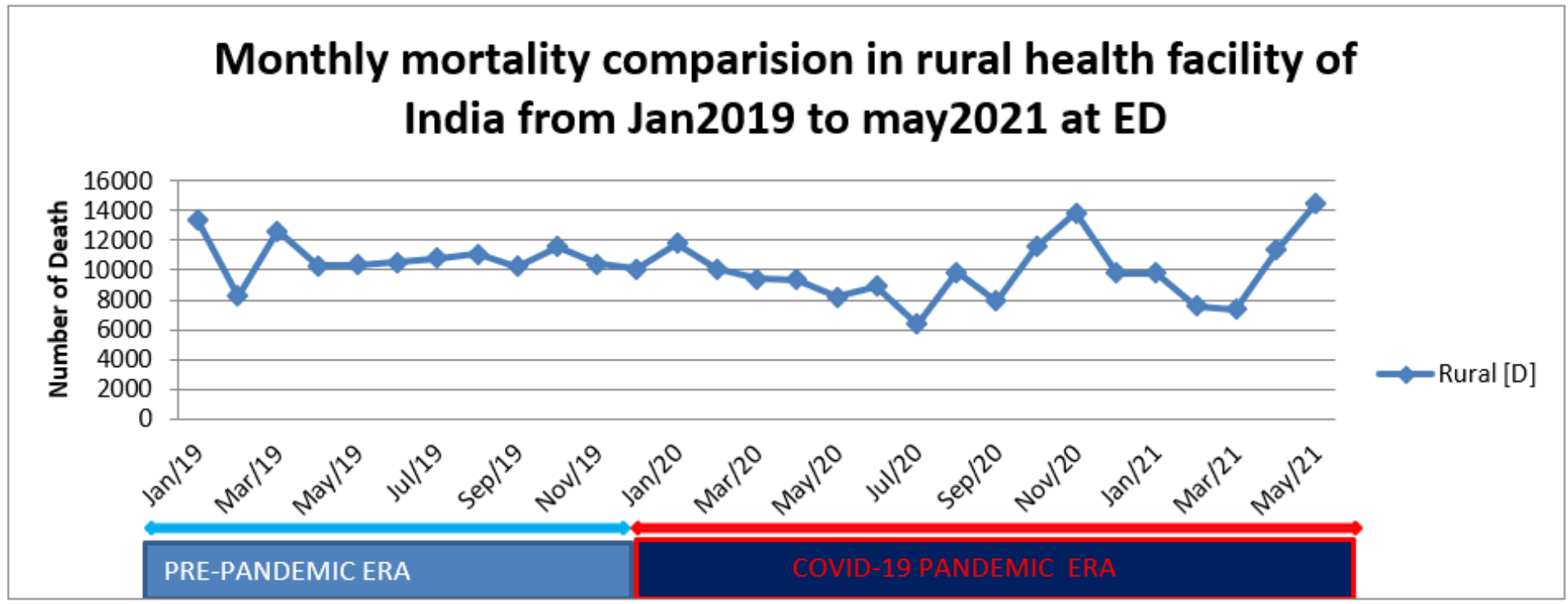

Figure 5

Monthly death comparison graph at ED of rural health facilities in India 